\title{
SELECTION BY PLACE OF BAPTISM AND AGE AT MARRIAGE OF SPOUSES IN A GOAN PARISH
}

\author{
Harish C. Srivastava \\ International Institute for Population Studies, \\ Deonar, Bombay, India
}

Résumé-Les archives ecclésiastiques, quoique disponibles en Inde, n'ont pas été utilisées jusqu'ici pour étudier les caractéristiques socio-démographiques durant les périodes antérieures. Ces archives fournissent une abondance de matériaux sur la démographie historique; toute tentative à explorer son utilité et à estimer la qualité de cette information, disponible en Inde, mérite d'être faite. La portée de cet exposé se limite à l'analyse des registres paroissiaux de mariage des jeunes mariées et des jeunes mariés et aussi à l'étude de l'âge au mariage des époux pour la période 1830 à 1913.

Abstract-Ecclesiastical records, though available in India, so far have not been used to study the socio-demographic characteristics in earlier periods. These records present a wealth of material on historical demography; any attempt to explore its utility and to appraise the quality of such information available in India, is worth undertaking. The scope of this paper is limited to the analysis of parish records of marriages of brides and grooms by place of baptism and also to the study of age at marriage of the spouses from the period 1830 to 1913.

Key words-parish (baptismal, ecclesiastical) records, age at marriage, India (Goa)

The use of ecclesiastical records for studying socio-demographic characteristics of early populations is a considerably new approach in the field of historical demography. The possibilities of discovery with implications for both social and economic history have led a growing number of scholars to examine data of a kind previously ignored. Valuable research in this area was done in several European countries and also in the United States. Some of the pioneering studies were undertaken in the European countries by researchers, viz., Eversley (1957), Krause (1958), Michalsen (1958), Karaman (1958), Drake (1962), Sogner (1963), Wrigley (April 1966 and spring 1968), Goubert (1965), Lassen (1965), etc. Some of the comparatively few studies based on parish registers done in the United States, Cook (1940), Aschmann (1959), Smith (1960), Demos (1965), etc., merit citation.

Ecclesiastical records, though available in India, so far have not been used in the sociodemographic study of earlier periods. These records contain a wealth of information on historical demography (see Srivastava, 1971). An attempt to explore their utility and to appraise the quality of such information, is worth making. Of late, this author has been studying the registers on baptism, marriage and burial in one of the parishes of Goa, India (Srivastava, 1972). However, the scope of this paper is limited to the analysis of marriage (of brides and grooms by place of baptism) and a study of age at marriage.

\section{Selection of the Parish}

Goa, a Union Territory (of India), is one place in the country where ecclesiastical records are available which can be utilized for studying long term trends in population. The parish of Taleigao, nearly five kilometres south-west of the city of Panaji, the capital of Goa, Daman and Diu was selected for the study. It is situated within Goa nearly 368 kilometres to the south of Bombay. Several factors were taken into account at the time of the selection of the parish. First, it must be of reasonable size; second, as far as possible, it should be a parish of staunch Catholics so that under-registration is minimum; thirdly, it should be inhabited mainly by 
Christians. An additional criterion was that it should be an area for which registers of marriage are available for the years under study.

\section{Source and Nature of Data}

Data for this study are based on the registers of marriage of Taleigao, one amongst the ancient parishes of Goa for which fairly complete ecclesiastical records are available. However, a few gaps in the data were noticed. Marriage records are highly disparate both in physical completeness and in comprehensiveness prior to 1830 . Therefore, this study is restricted to the period 1830-1913. Necessary information needed for the study was entered on forms especially designed for the purpose. Place of baptism of the brides and grooms is divided into three broad categories, viz., (i) baptized in the same parish (the parish in question) (ii) baptized in the adjacent parish (any other parish situated at a distance of five kilometres from Taleigao and (iii) baptized at a distant parish (at a distance of more than five kilometres away). The whole period under study has been divided into decades except for the last four years (1910-1913).

\section{Analysis}

Relevant information based on the registers for the years 1830 to 1913 could be collected for 2119 brides and grooms. A linear function was fitted to the observed data on the number of marriages in each year and the figures were estimated for the years for which data were not available. These estimated figures have also been used for plotting the graph which shows an increasing trend. It is evident from the graph that during the $1860 \mathrm{~s}, 1870 \mathrm{~s}$ and $1890 \mathrm{~s}$ lesser number of marriages were performed, the probable reason for which may be the political disturbances in Goa during that period viz., Custoba's revolt in 1889, the army revolt of Volpoi Matasheli in 1870 and Dada Rane's revolt in 1895 (see Saldana, 1957 and Figueiredo, 1961). These upheavals in Goa might have affected the parish of Taleigao. Another reason might have been the high mortality rates prevalent in those decades which might have resulted in the deaths of young persons of marriageable age.

The data can be used to cross-classify marriage by place of baptism of both the spouses. The maximum number of marriages were contracted between partners both of whom had been baptized within the parish of Taleigao (Table 1). Interestingly enough, during the 1880-89 decade, out of 292 brides 86.64 per cent were baptized in the parish of Taleigao. A glance at Table 1 indicates that at the time of selecting brides preference was given to girls baptized in distant parishes as compared to those from adjacent parishes.

During the 1880 s and also during 1900-1909, significant proportions, 85.71 per cent and 94.74 per cent respectively, were of such marriages where bridegrooms were baptized in the adjacent parishes.

While considering those bridegrooms who were baptized in the distant parishes it was found that most of them had chosen partners baptized in the parish of Taleigao. As is evident from the table, during the 1890 s a maximum number of brides ( 88.46 per cent) had selected their husbands who were baptized in distant parishes.

Also noteworthy is that among 2,119 marriages over the entire period, 125 brides of the same parish (5.9 per cent) had chosen their partners from the adjacent parishes. 34 marriages (1.61 per cent) were such where both the spouses were drawn from distant parishes.

Nonavailability of data on age at marriage of the brides and grooms prior to 1860 has left us no choice but to confine the analysis to the period 1860-1913 (Table 2).

It was found that the mean age at marriage for both the spouses was almost the same over time; while girls were getting married at the age of 18 or 19 years, boys were married on an average, at the age of 26 or 27 years. The mean age at marriage for boys during the 1860 s was the highest (30.5 years) and there was a decline thereafter. 
Selection by Place of Baptism and Age at Marriage

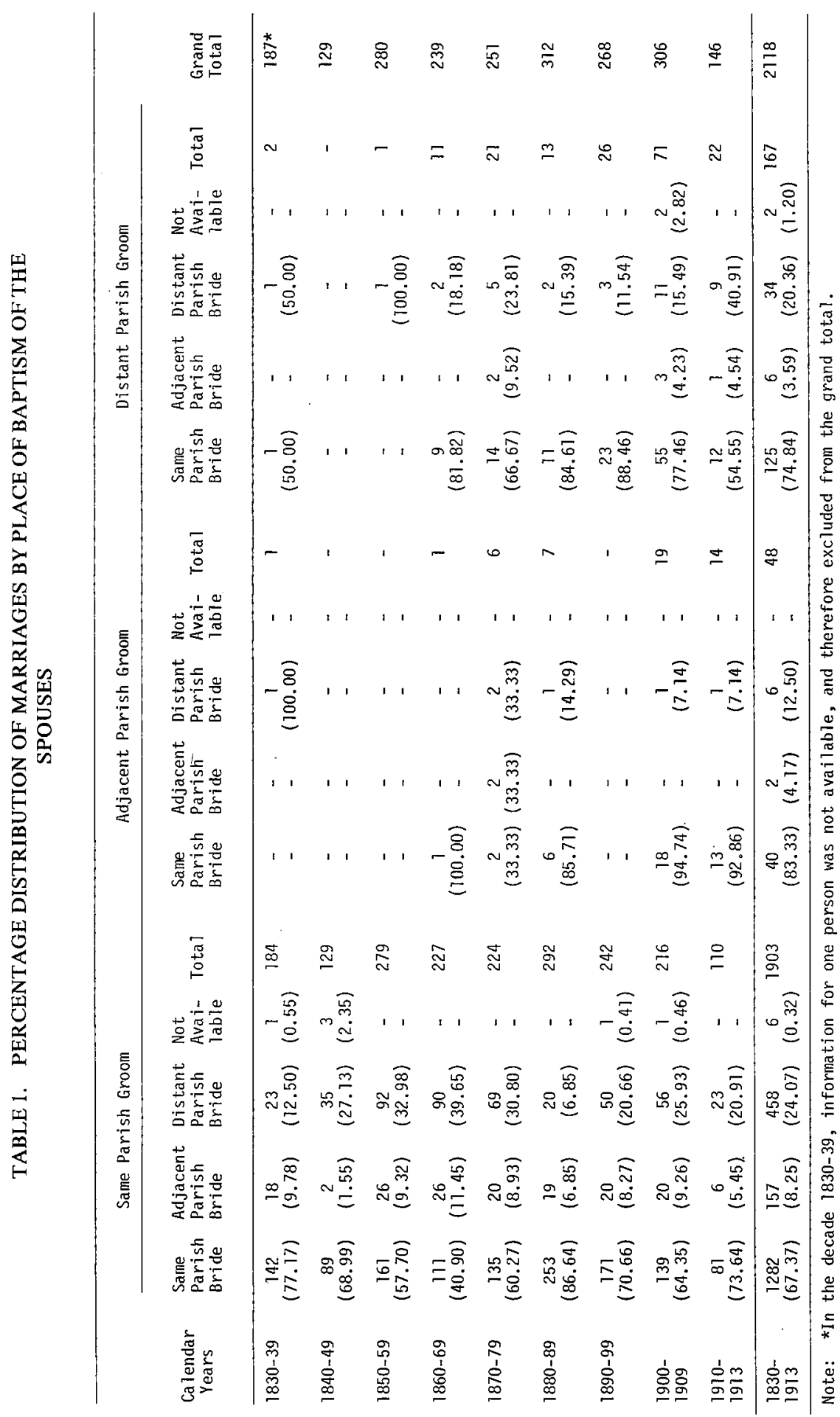


Harish C. Srivastava

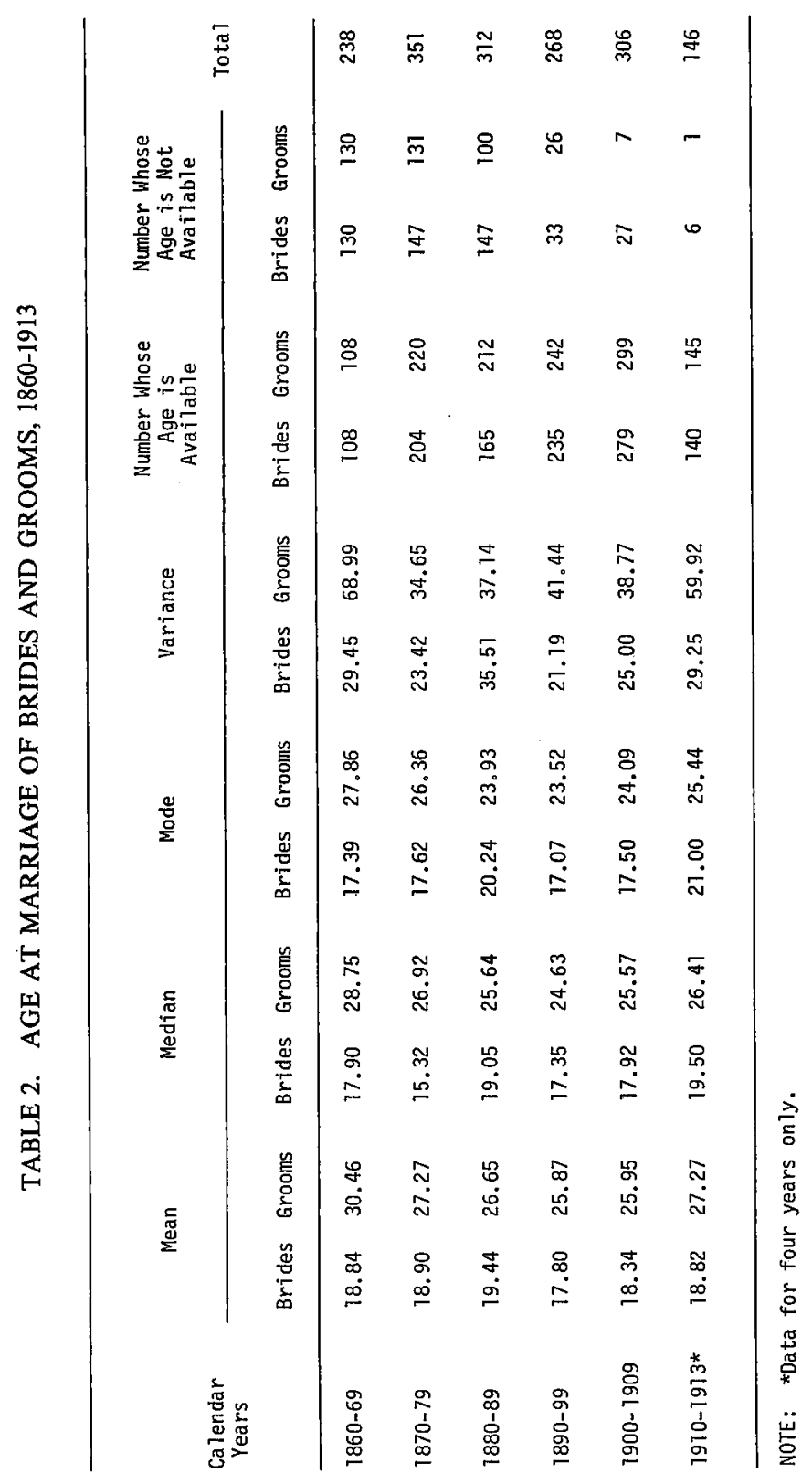




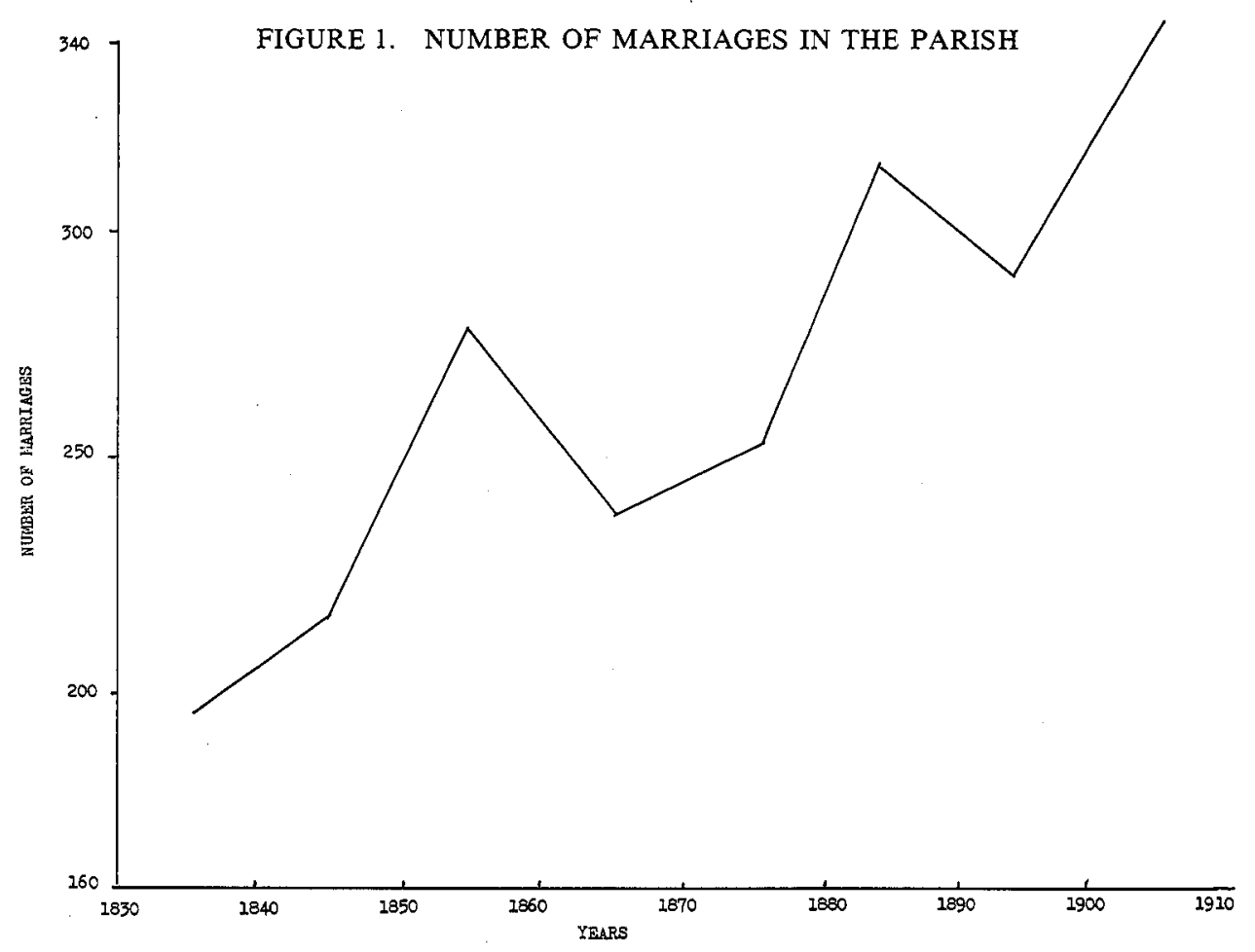

The other two statistical indicators, namely, the median and the modal ages of the spouses, have shown a similar trend during the period 1860-1913. In the case of the males median and modal ages have recorded a continuous decline up to 1899 . However, these ages have shown an increasing trend during 1900-1909 and 1910-1913. This seems to be quite interesting and needs further investigations. In the case of females, median and modal ages have exhibited more fluctuations. However, a continuous rise in both the median and the modal ages is ostensible after 1899. Smith (1960-61) has also used parish records of marriage and found that most of the girls were married between the ages of 15 and 21 , the most popular age for marriage being 16 to 18 years.

\section{Summary}

An attempt has been made in this study to throw some light on the practices of spouse selection in the late 19th and early 20th century in an Indian parish, situated in Goa, by utilizing old ecclesiastical marriage records.

It has been observed that at the time of selecting spouses, first preference was given to those who were baptized within the parish, as the highest proportion of marriages was contracted between such partners. While selecting brides, it seems, those from the distant parishes were preferred to those baptized in adjacent parishes. A tiny proportion (1.61 per cent) was between partners both of whom were baptized in the distant parishes; their marriages were registered in the old ecclesiastical records of the parish under study.

Depending upon the availability of the data, statistical measures of age at marriage for boys and girls, married in the parish of Taleigao, have been calculated. It was found that the mean age at marriage for both the spouses was almost the same over time. Girls were married 
at the age of 18 or 19 years while for boys the average age of marriage was found to be 26 or 27 years. The highest mean age at marriage for boys was 30.5 years during the 1860 s which was followed by a decline thereafter. The other two indicators, namely, median and modal ages of the spouses had shown a similar trend during the years 1860 to 1913. Compared to the male, more fluctuations were found in the female median and modal ages. However, after 1899 a continuous rise in both the median and the modal ages of the brides was ostensible.

The evidence gathered hitherto reveals that significant changes in the parish took place from 1860 to 1913 and the information available in the ecclesiastical records during this period is more comprehensive than in earlier periods.

\section{Acknowledgment}

The author is grateful to Dr. J. R. Rele, Director, International Institute for Population Studies, Bombay, for his encouragement and also for providing necessary facilities for research in connection with this paper. Thanks are also due to Dr. P. C. Saxena of the Institute for his helpful comments. The author also wishes to acknowledge the suggestions of two anonymous referees.

\section{References}

Aschmann, Homer. 1959. The Central Desert of Baja, California: Demography and Ecology. IberoAmericana, 42. Berkeley: University of California Press.

Cook, S. F. 1940. Population Trends among the California Mission Indians. Berkeley: University of California Press.

Demos, John. 1965. Notes on Life in Plymouth Colony. William and Mary Quarterly, 3rd series, 22(2):264-286.

Drake, M. 1962. An Elementary Exercise in Parish Register Demography. The Economic History Review, 2nd series, 14(3):427-445.

Eversley, D. E. C. 1957. A Survey of Population in an area of Worcestershire, 1660-1850. Population Studies 10:253-279.

Figueiredo, Antonio de. 1961. Portugal and Its Empire: The Truth. London: V. Gollancz.

Goubert, Pierre. 1965. Recent Theories and Research in French Population between 1500 and 1700. In D. V. Glass and D. E. C. Eversley (eds.), Population in History: Essays in Historical Demography. London: Edward Arnold.

Karaman, I. 1958. Protection of old Parish Registers on the Territory of Federative People Republic Yugoslavia. Archivum 8:115-116.

Krause, J. T. 1958. Changes in English Fertility and Mortality, 1781-1850. The Economic History Review, 2nd series, 11(1):52-70.

Lassen, A. 1965. The Population of Denmark in 1660. Scandinavian Economic History Review 13:1-30.

Michalsen, F. 1958. Church registers in Norway. Archivum 8:43-53.

Saldana, C. P. 1957. A Short History of Goa. Goa.

Smith, T. E. 1960. The Cocos — Keeling Islands: A Demographic Laboratory. Population Studies 14:94130.

Sogner, S. 1963. Aspects of the Demographic Situation in 17 Parishes in Shropshire, 1711-60. An Exercise Based on Parish Registers. Population Studies 17:126-146.

Srivastava, Harish C. 1971. Registration of Vital Events in Goa - A Study of the Current System in Retrospect. Arthavijnana 13(4): 458-468.

1972. Birth and Death Rates in Goa: An Appraisal of Parish Registers. Bombay: International Institute for Population Studies.

Wrigley, E. A. 1966. Family Limitation in Pre-Industrial England. The Economic History Review, 2nd series, 19(1):82-109.

1968. Mortality in Pre-Industrial England: The Example of Colyton, Devon, over Three Centuries. Daedalus 97:546-580. 